\title{
32. GENESIS OF CALC-ALKALINE MAGMAS: EXPERIMENTS WITH PARTIAL MELTING OF MIXED SEDIMENTS AND BASALTS FROM THE MIDDLE AMERICA TRENCH, SOUTHERN MEXICO TRANSECT ${ }^{1}$
}

\author{
I. D. Ryabchikov, A. D. Babansky, and Y. I. Dmitriev, Institute of Geology of Ore Deposits, Petrology, \\ Mineralogy and Geochemistry, USSR Academy of Sciences, Moscow, USSR
}

\section{INTRODUCTION}

It is widely accepted that the calc-alkaline magmatism of active continental margins is caused by the melting of ocean crust in subduction zones, which in turn is due to the interaction of lithospheric plates (Dickinson, 1970; Fitton, 1971; Green, 1972). In particular, the Neogene-Quaternary magmatism of Central America is considered to be the result of the subduction of the Cocos Plate under the continent of North America in the zone of the Middle America Trench (Pichler and Weyl, 1973; Stoiber and Carr, 1974).

Recent investigations (Magaritz et al., 1978; Stern, 1974) show that the direct melting of ocean crust basalts does not result in the formation of calc-alkaline magmas, and the models of the generation of these melts would not be complete without taking into account both the processes of magmatic differentiation and their interaction with the sialic material of ocean and continental crust.

Metagreywackes from the blueschist belts are often used as a model rock for determining geochemical characteristics of material assimilated during the generation of calc-alkaline magmas (James, 1978). It also seemed to us interesting to conduct experimental melting of mixtures of the sediments and basalts that are found in the zones of destruction of lithospheric plates and whose analogs may undergo similar melting in subduction zones under continents. The rocks recovered from Hole 487 by Leg 66 proved ideal for such experiments.

Hole $487\left(15^{\circ} 51.21^{\prime} \mathrm{N}, 99^{\circ} 10.52^{\prime} \mathrm{W}\right)$ was drilled in the northern part of the Cocos Plate on the seaward side of the Middle America Trench, $11 \mathrm{~km}$ from its axis.

The following rocks are present (from the top downward) in this hole at a water depth of 4764 meters:

1) Grayish olive mud composed of clay and aleurolitic material that in turn contains quartz, feldspars, and volcanic glass; Pleistocene; thickness, 155 meters.

2) Brown pelagic clays together with layers of volcanic ash; Miocene-Pliocene; thickness, 55 meters.

3) Olivine-plagiophyric, plagiophyric, and aphyric basalts; thickness, more than $2 \mathrm{~km}$.

Chemical analyses of the rocks from Hole 487 made at the central chemical laboratory of the Institute for

\footnotetext{
1 Initial Reports of the Deep Sea Drilling Project, Volume 66.
}

Geology of Ore Deposits, Petrography, Mineralogy, and Geochemistry of the USSR Academy of Sciences by Yu.V. Dolinina (Tables 1, 2, 3) and determined the composition of the upper part of the cross section of ocean crust in the zone of its assumed subduction under continental plate.

Analyses of the sediment samples (Tables 1 and 2), in a state of natural humidity and after drying at $110^{\circ} \mathrm{C}$, show that all of them contain from $42 \%$ to $46 \%$ porous water and that on heating they lose not only water but also such volatile components as fluorine and chlorine.

Brown clays in the lower part of sedimentary layer differ from the overlying muds by their lower $\mathrm{SiO}_{2}$, $\mathrm{TiO}_{2}$, and $\mathrm{K}_{2} \mathrm{O}$ content and by markedly higher concentrations of iron and manganese. Iron content increases and $\mathrm{TiO}_{2}$ and potassium concentrations decrease with depth.

Inasmuch as grayish olive muds predominate among the sediments of Hole 487, Sample 487-10-3, 48-50 cm, which is representative in composition, was chosen for experiments.

Aphyric, plagiophyric, and olivine-plagiophyric components occur among the basalts of Hole 487 (Table 3), which on the basis of their chemistry (Table 4) may be subdivided into normal tholeiitic basalts (aphyric and olivine-plagiophyric basalts) and high-alumina tholeiitic basalts (plagiophyric basalts).

Because olivine-plagiophyric components make up two-thirds the length of drill core, Sample 487-20-2, 50$56 \mathrm{~cm}$, which is typical of this suite, was also selected for the melting experiments.

\section{METHODS}

We conducted two series of experiments with the rock samples. The first was the partial melting of a thoroughly homogenized mixture of tholeiitic basalt (Table 5, analysis 1) and grayish olive mud (Table 5, analysis 2 ) in the proportion $0.34: 0.66$, respectively. This proportion was calculated by the least squares method and is the best approximation to the basaltic andesite from the Paricutin volcano in Mexico (Williams, 1950), which is typical. This rock type predominates among the effusives of that region of adjacent continent (Table 5 , analyses 3 and 4).

In the second experiment the specimen consisted of two layers: the lower layer was tholeiitic basalt and the layer above was dried mud.

Experimental conditions were as follows: pressure, 1 atm.; temperature, $1170^{\circ} \mathrm{C}$; duration of runs, 170 hours; oxygen fugacity was controlled by a hematite-magnetite buffer. Starting powders were placed in platinum capsules. After quenching, we made thin sections, which were examined under microscope and their glass content analyzed by electron microprobe. 
Table 1. Chemical composition of grayish olive muds from Hole 487 (wt. \%).

\begin{tabular}{|c|c|c|c|c|c|c|c|c|c|c|}
\hline & \multicolumn{2}{|c|}{$\begin{array}{c}\text { Sample } 487-2-3 \text {, } \\
48-50 \mathrm{~cm}\end{array}$} & \multicolumn{2}{|c|}{$\begin{array}{c}\text { Sample } 487-6-3, \\
48-50 \mathrm{~cm}\end{array}$} & \multicolumn{2}{|c|}{$\begin{array}{c}\text { Sample } 487-10-3 \\
48-50 \mathrm{~cm}\end{array}$} & \multicolumn{2}{|c|}{$\begin{array}{c}\text { Sample } 487-13-3 \text {, } \\
48-50 \mathrm{~cm} \\
\end{array}$} & \multicolumn{2}{|c|}{$\begin{array}{c}\text { Average of the } \\
4 \text { Samples }\end{array}$} \\
\hline & Wet & $\begin{array}{c}\text { Dried } \\
\left(110^{\circ} \mathrm{C}\right)\end{array}$ & Wet & $\begin{array}{c}\text { Dried } \\
\left(110^{\circ} \mathrm{C}\right)\end{array}$ & Wet & $\begin{array}{c}\text { Dried } \\
\left(110^{\circ} \mathrm{C}\right)\end{array}$ & Wet & $\begin{array}{c}\text { Dried } \\
\left(110^{\circ} \mathrm{C}\right)\end{array}$ & Wet & $\begin{array}{c}\text { Dried } \\
\left(110^{\circ} \mathrm{C}\right)\end{array}$ \\
\hline $\mathrm{SiO}_{2}$ & 29.45 & 52.40 & 28.29 & 48.45 & 29.70 & 51.20 & 27.62 & 50.40 & 28.76 & 50.61 \\
\hline $\mathrm{TiO}_{2}$ & 0.46 & 0.82 & 0.45 & 0.79 & 0.44 & 0.80 & 0.35 & 0.60 & 0.42 & 0.75 \\
\hline $\mathrm{Al}_{2} \mathrm{O}_{3}$ & 10.00 & 17.00 & 10.06 & 17.15 & 10.29 & 18.10 & 8.81 & 16.40 & 9.79 & 17.16 \\
\hline $\mathrm{Fe}_{2} \mathrm{O}_{3}$ & 2.40 & 2.94 & 2.19 & 3.08 & 3.67 & 5.13 & 4.24 & 7.38 & 3.12 & 4.63 \\
\hline $\mathrm{FeO}$ & 1.06 & 2.75 & 0.90 & 2.76 & 0.75 & 1.73 & 0.38 & 1.68 & 0.77 & 2.23 \\
\hline $\mathrm{MnO}$ & 0.15 & 0.24 & 1.82 & 2.73 & 0.08 & 0.16 & 0.14 & 0.15 & 0.55 & 0.82 \\
\hline $\mathrm{MgO}$ & 2.68 & 3.12 & 3.15 & 3.09 & 2.08 & 3.56 & 2.01 & 3.67 & 2.48 & 3.36 \\
\hline $\mathrm{CaO}$ & 0.90 & 1.66 & 1.58 & 2.10 & 1.22 & 1.22 & 1.29 & 1.54 & 1.25 & 1.63 \\
\hline $\mathrm{Na}_{2} \mathrm{O}$ & 2.22 & 3.84 & 2.03 & 3.48 & 2.05 & 3.70 & 2.24 & 4.12 & 2.13 & 3.78 \\
\hline $\mathrm{K}_{2} \mathrm{O}$ & 1.74 & 2.79 & 1.54 & 2.78 & 1.52 & 2.77 & 1.39 & 2.58 & 1.55 & 2.73 \\
\hline $\mathrm{H}_{2} \mathrm{O}^{-}$ & 43.12 & 0.38 & 42.66 & 0.51 & 41.63 & 0.15 & 46.55 & 0.26 & 43.49 & 0.32 \\
\hline $\mathrm{H}_{2} \mathrm{O}^{+}$ & 4.08 & 9.43 & 4.17 & 9.91 & 5.07 & 8.40 & 3.78 & 8.58 & 4.27 & 9.08 \\
\hline F & 0.04 & 0.02 & 0.03 & 0.03 & 0.04 & 0.05 & 0.03 & 0.05 & 0.03 & 0.04 \\
\hline $\mathrm{Cl}$ & 1.72 & 1.94 & 1.49 & 1.98 & 1.97 & 2.06 & 1.69 & 2.46 & 1.72 & 2.11 \\
\hline $\mathrm{S}$ & 0.18 & 0.39 & 0.16 & 0.35 & 0.24 & 0.43 & 0.07 & 0.17 & 0.16 & 0.33 \\
\hline $\mathrm{P}_{2} \mathrm{O}_{5}$ & 0.028 & 0.13 & 0.027 & 0.15 & - & 0.14 & 0.08 & 0.33 & n.d. & 0.43 \\
\hline $\mathrm{CO}_{2}$ & n.d. & 0.34 & n.d. & 0.64 & n.d. & 0.49 & n.d. & 0.26 & n.d. & n.d. \\
\hline $\mathrm{Cr}_{2} \mathrm{O}_{3}$ & 0.008 & n.d. & 0.004 & n.d. & 0.07 & n.d. & 0.01 & n.d. & 0.03 & n.d. \\
\hline $\mathrm{v}_{2} \mathrm{O}_{5}$ & 0.018 & n.d. & 0.009 & n.d. & 0.020 & n.d. & 0.014 & n.d. & 0.02 & n.d. \\
\hline Total & 100.26 & 100.19 & 100.57 & 99.98 & 100.78 & 100.09 & 100.71 & 100.63 & 100.54 & 100.01 \\
\hline
\end{tabular}

Note: n.d. $=$ not determined.

Table 2. Chemical composition of brown clays from Hole 487 (wt. $\%$ ).

\begin{tabular}{|c|c|c|c|c|c|c|}
\hline & \multicolumn{2}{|c|}{$\begin{array}{c}\text { Sample 487-14-3, } \\
48-50 \mathrm{~cm}\end{array}$} & \multicolumn{2}{|c|}{$\begin{array}{c}\text { Sample } 487-18-3, \\
68-70 \mathrm{~cm} \\
\end{array}$} & \multicolumn{2}{|c|}{$\begin{array}{l}\text { Average of the } \\
2 \text { Samples }\end{array}$} \\
\hline & Wet & $\begin{array}{c}\text { Dried } \\
\left(110^{\circ} \mathrm{C}\right)\end{array}$ & Wet & $\begin{array}{c}\text { Dried } \\
\left(110^{\circ} \mathrm{C}\right)\end{array}$ & Wet & $\begin{array}{l}\text { Dried } \\
\left(110^{\circ} \mathrm{C}\right)\end{array}$ \\
\hline $\mathrm{SiO}_{2}$ & 24.13 & 39.20 & 23.95 & 42.70 & 24.04 & 40.95 \\
\hline $\mathrm{TiO}_{2}$ & 0.29 & 0.50 & 0.22 & 0.40 & 0.25 & 0.45 \\
\hline $\mathrm{Al}_{2} \mathrm{O}_{3}$ & 7.18 & 10.10 & 6.17 & 9.45 & 6.67 & 9.77 \\
\hline $\mathrm{Fe}_{2} \mathrm{O}_{3}$ & 10.11 & 16.40 & 10.20 & 16.15 & 10.15 & 16.27 \\
\hline $\mathrm{FeO}$ & - & - & - & - & - & - \\
\hline $\mathrm{MnO}$ & 3.51 & 8.30 & 2.76 & 5.45 & 2.83 & 6.87 \\
\hline $\mathrm{MgO}$ & 1.62 & 2.56 & 2.29 & 3.42 & 1.95 & 2.99 \\
\hline $\mathrm{CaO}$ & 1.34 & 2.21 & 1.02 & 1.49 & 1.18 & 1.85 \\
\hline $\mathrm{Na}_{2} \mathrm{O}$ & 2.31 & 3.45 & 2.08 & 3.59 & 2.19 & 3.52 \\
\hline $\mathrm{K}_{2} \mathrm{O}$ & 1.41 & 1.90 & 1.08 & 1.85 & 1.24 & 1.87 \\
\hline $\mathrm{H}_{2} \mathrm{O}^{-}$ & 42.21 & - & 44.26 & 0.11 & 43.23 & 0.05 \\
\hline $\mathrm{H}_{2} \mathrm{O}^{+}$ & 4.23 & 11.79 & 4.67 & 13.22 & 4.45 & 12.05 \\
\hline$F^{2}$ & 0.03 & 0.05 & 0.03 & 0.03 & 0.03 & 0.04 \\
\hline $\mathrm{Cl}$ & 1.88 & 2.23 & 1.62 & 1.71 & 1.75 & 1.97 \\
\hline S & 0.11 & 0.22 & 0.07 & 0.16 & 0.09 & 0.19 \\
\hline $\mathrm{P}_{2} \mathrm{O}_{5}$ & 0.25 & 0.69 & 0.14 & 0.48 & 0.19 & 0.58 \\
\hline $\mathrm{CO}_{2}$ & n.d. & 0.46 & n.d. & 0.34 & n.d. & 0.40 \\
\hline $\mathrm{Cr}_{2} \mathrm{O}_{3}$ & 0.001 & n.d. & 0.008 & n.d. & 0.004 & n.d. \\
\hline $\mathrm{V}_{2} \mathrm{O}_{5}$ & 0.045 & n.d. & 0.039 & n.d. & 0.042 & n.d. \\
\hline Total & 100.66 & 100.06 & 100.61 & 100.55 & 100.29 & 99.82 \\
\hline
\end{tabular}

Note: n.d. = not determined.

\section{RESULTS}

In experiments with the homogenized mixture of tholeiitic basalt and mud, the quenched material consisted of large and small sillimanite crystals, less abundant plagioclase grains, and rounded polycrystalline aggregates probably built up from the tiny grains of sillimanite. Crystalline phases are immersed in glass (Table 6, analysis 1), parts of which are full of finely dispersed opaque mineral.

Experiments with the layered specimen revealed the following zones (in deepening succession):
Table 3. Quantitative mineralogical composition of basalts from Hole 487 (vol. \%).

\begin{tabular}{|c|c|c|c|c|c|}
\hline \multirow[b]{2}{*}{ Component } & \multicolumn{2}{|c|}{$\begin{array}{l}\text { Plagiophyric } \\
\text { Basalts }\end{array}$} & \multicolumn{3}{|c|}{$\begin{array}{c}\text { Olivine-Plagiophyric and } \\
\text { Aphyric Basalts }\end{array}$} \\
\hline & $\begin{array}{l}\text { Limits of } \\
\text { Variation }\end{array}$ & $\begin{array}{c}\text { Mean } \\
\text { of } 3\end{array}$ & $\begin{array}{l}\text { Limits of } \\
\text { Variation }\end{array}$ & $\begin{array}{c}\text { Mean } \\
\text { of } 7\end{array}$ & $\begin{array}{c}\text { Sample } 487-20-2, \\
50-56 \mathrm{~cm}\end{array}$ \\
\hline \multicolumn{6}{|l|}{ Phenocrysts: } \\
\hline Plagioclase & $0.6-2.3$ & 1.5 & $0.0-11.6$ & 3.9 & 1.7 Ang0-85 \\
\hline Olivine & - & - & $0.0-1.2$ & 0.4 & $\mathrm{Fa}_{11}$ \\
\hline Spinel & $0.0-0.2$ & 0.1 & r.g. & r.g. & $\begin{array}{l}3 \mathrm{Al}_{2} \mathrm{O}_{3}- \\
31.7 \mathrm{Cr}_{2} \mathrm{O}_{3}\end{array}$ \\
\hline \multicolumn{6}{|l|}{ Groundmass: } \\
\hline Plagioclase & $26.0-44.6$ & 35.1 & $26.6-40.4$ & 34.1 & 28.3 An77 \\
\hline Clinopyroxene & $2.1-50.0$ & 18.7 & $2.8-63.1$ & 22.6 & $\begin{array}{l}63.1 \text { En } 43-38 \\
\text { Wo } 37-42 \\
\text { Fs } 25-15\end{array}$ \\
\hline Olivine & r.g. & r.g. & $0.0-0.4$ & 0.1 & 0.4 \\
\hline Titanomagnetite & \multicolumn{2}{|c|}{ in mesostasis } & up to 3.1 & 0.6 & $1.0 \mathrm{TiO}_{2} 16$ \\
\hline Mesostasis & $3.8-69.4$ & 44.7 & $0.0-59.6$ & 38.1 & - \\
\hline $\begin{array}{l}\text { Secondary } \\
\text { minerals }\end{array}$ & up to 1.8 & 0.3 & up to 5.5 & 0.3 & 5.5 \\
\hline
\end{tabular}

Note: G. N. Muravitskaya of the Institute for Geology of Ore Deposits, Petrography, Mineralogy and Geochemistry of the USSR Academy of Sciences determined chemical compositions of rock-forming minerals by electron microprobe. r.g. = rare grains.

1) The upper zone of the pelitic layer contains plagioclase and high-alumina phase (sillimanite), a few grains of ore minerals, and numerous very fine aggregates (probably unreacted starting rock) in transparent colorless glass (Table 6, analysis 6).

2) The intermediate zone is mainly glass (Table 6, analysis 5), with a few envelope-shaped plagioclase crystals.

3) The lower (contact) zone is plagioclase plus highalumina phase (sillimanite) plus a few grains of opaque mineral plus glass (Table 6, analysis 4).

4) The upper (contact) zone of the basaltic layer consists of olivine, plagioclase, numerous grains of opaque mineral, and fine aggregates of undetermined mineralogical composition. Glass in this zone has brown patches. 
Table 4. Chemical composition of basalts from Hole 487 (wt. \%).

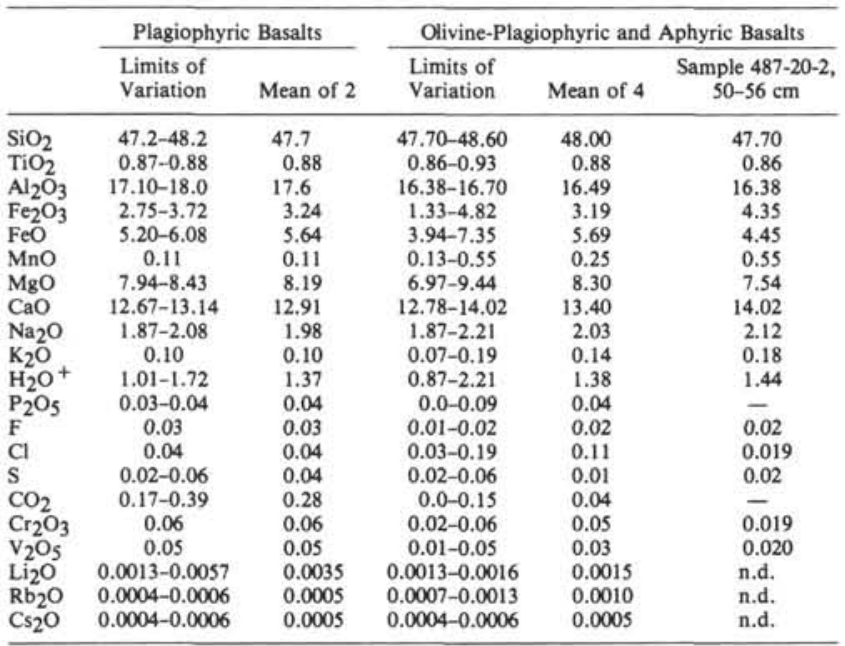

Note: n.d. $=$ not determined.

Table 5. Chemical composition of rocks and mixtures used for experiments (wt. \%).

\begin{tabular}{lrrrr}
\hline Component & \multicolumn{1}{c}{1} & \multicolumn{1}{c}{2} & \multicolumn{1}{c}{3} & \multicolumn{1}{c}{4} \\
\hline $\mathrm{SiO}_{2}$ & 48.82 & 58.18 & 54.90 & 57.45 \\
$\mathrm{TiO}_{2}$ & 0.88 & 0.91 & 0.89 & 0.92 \\
$\mathrm{Al}_{2} \mathrm{O}_{3}$ & 16.76 & 20.57 & 19.50 & 18.16 \\
$\mathrm{FeO}$ & 9.12 & 7.40 & 7.92 & 6.33 \\
$\mathrm{MgO}$ & 7.72 & 4.05 & 5.24 & 5.04 \\
$\mathrm{CaO}$ & 14.35 & 1.39 & 5.93 & 7.03 \\
$\mathrm{Na}_{2} \mathrm{O}$ & 2.17 & 4.20 & 3.50 & 3.72 \\
$\mathrm{~K}_{2} \mathrm{O}$ & 0.18 & 3.15 & 2.12 & 1.34 \\
\hline
\end{tabular}

Note: Analyses are given without volatiles and are recalculated to $100 \%$. Total iron is represented as $\mathrm{FeO}$.

1 = olivine-plagiophyric basalt, Sample 48720-2, $56 \mathrm{~cm}$ (cf. Table 4).

$2=$ grayish olive mud, Sample 487-10-3, 50 $\mathrm{cm}$.

$3=$ composition of mixture $0.34(1)+0.66$ (2) (see text).

$4=$ mean composition of basaltic andesite from the Paricutin volcano in Mexico, calculated from five analyses by Williams (1950).

5) The lower zone consists of large equant olivine crystals and smaller prismatic plagioclase grains. Glass is uniformly brownish (Table 6 , analysis 2 ).

\section{DISCUSSION}

Before analyzing the experimental data, let us first consider certain points that in our opinion justify the experiments described in the foregoing.

Many authors (e.g., Stern, 1974; Dickinson, 1973) have suggested that the formation of andesites and related magmas takes place at depths of approximately $100 \mathrm{~km}$ - that is, at pressures of 25 to $30 \mathrm{kbar}$. This suggestion is based mainly on the correlation of geochemical features of calc-alkaline magmas with the depth to Benioff Zone and on the physicochemical model of the secondary melting of basaltic material transformed into quartz-bearing eclogites (Ringwood, 1974). However,
Table 6. Composition of quenched glasses produced through experiments with rock mixtures.

\begin{tabular}{lrrrrrr}
\hline Component & \multicolumn{1}{c}{1} & \multicolumn{1}{c}{2} & \multicolumn{1}{c}{3} & \multicolumn{1}{c}{4} & \multicolumn{1}{c}{5} & \multicolumn{1}{c}{6} \\
\hline $\mathrm{SiO}_{2}$ & 61.37 & 52.85 & 57.09 & 68.62 & 65.25 & 66.88 \\
$\mathrm{TiO}_{2}$ & 1.10 & 1.27 & 1.11 & 0.88 & 0.86 & 1.14 \\
$\mathrm{Al}_{2} \mathrm{O}_{3}$ & 18.05 & 14.62 & 15.58 & 19.65 & 19.58 & 19.32 \\
$\mathrm{FeO}$ & 4.59 & 8.40 & 7.12 & 2.11 & 3.35 & 3.99 \\
$\mathrm{MgO}$ & 5.13 & 8.19 & 5.73 & 1.44 & 3.15 & 1.35 \\
$\mathrm{CaO}$ & 5.13 & 11.70 & 9.45 & 2.37 & 3.15 & 3.22 \\
$\mathrm{Na} 2 \mathrm{O}$ & 2.36 & 2.24 & 2.51 & 1.54 & 1.62 & 0.98 \\
$\mathrm{~K}_{2} \mathrm{O}$ & 2.27 & 0.73 & 1.41 & 3.39 & 3.04 & 3.12 \\
\hline
\end{tabular}

Note: Analyses are given without volatiles and are recalculated to $100 \%$. Total iron is shown as $\mathrm{FeO}$.

1 = mean composition of quenched glass from experiments with a homogenized mixture of 0.34 basalt +0.66 mud; 2 and 3 are glasses from the basaltic layer of the two-layered experiments.

$2=$ glass from the lower zone.

3 = glass from the upper zone (contact); 4-6 are glasses from the pelitic layer of the two-layered experiment.

4 = glass from the lower zone (contact).

$5=$ glass from the intermediate zone.

$6=$ glass from the upper zone. (See text.) The analyst was G. N. Muravitskaya, using an MS-46 (Comeca) instrument for microprobe analysis.

the complete absence of the xenoliths of mantle rocks from andesites and the way in which the evolution of the composition of calc-alkaline magmas closely follows the variations established by experiments at pressures from 1 atm. to 4 kbar (Ryabchikov et al., 1979) suggest that calc-alkaline magmas may be formed and differentiated at much shallower depths. Because of this our preliminary experiments were made at $1 \mathrm{~atm}$. One may also note that the increase in pressure from $1 \mathrm{~atm}$. to several kilobars does not significantly affect phase relations in dry magmas.

We may further point out that the contribution of sedimentary rocks to the bulk composition of ocean crust is minor. However, the calculated distribution of temperatures in the subducted lithospheric plates shows that the hottest parts where the partial melting of lithosphere may take place are situated near the boundary surfaces (Oxburgh and Turcotte, 1970). Because of this, the proportion of sedimentary material near such boundaries in the zones of partial melting may be quite substantial, a possibility we took into account in planning the present experiments.

Even the simple balance of mass calculations shows that the composition of sediment and basalt mixtures, most common in the zones of oceanic margins, may closely match that of more basic members of the calc-alkaline volcanic series (Table 5, analyses 3 and 4). Our experiments demonstrated that partial melting of such compositions may result in the production of melts very similar to typical andesites. The comparison of the composition of glass produced in our experiments with that of andesite from the Paricutin volcano (Eggler, 1972) in Table 7 (analyses 1 and 2) shows that the contents of the majority of oxides in these specimens are fairly similar. Thus it is the extent of partial melting of the mixture of tholeiitic basalts and ocean sediments 
Table 7. Comparison of the composition of quenched glasses from our experiments and from effusive and igneous rocks (see text).

\begin{tabular}{lrrrrrr}
\hline Component & \multicolumn{1}{c}{1} & \multicolumn{1}{c}{2} & \multicolumn{1}{c}{3} & \multicolumn{1}{c}{4} & \multicolumn{1}{c}{5} & \multicolumn{1}{c}{6} \\
\hline $\mathrm{SiO}_{2}$ & 61.37 & 61.05 & 57.09 & 57.45 & 68.62 & 66.9 \\
$\mathrm{TiO}_{2}$ & 1.10 & 0.92 & 1.11 & 0.92 & 0.88 & 0.7 \\
$\mathrm{Al}_{2} \mathrm{O}_{3}$ & 18.05 & 17.46 & 15.58 & 18.16 & 19.65 & 15.5 \\
$\mathrm{FeO}$ & 4.59 & 3.34 & 7.12 & 6.33 & 2.11 & 5.0 \\
$\mathrm{MgO}$ & 5.13 & 3.83 & 5.73 & 5.04 & 1.44 & 2.5 \\
$\mathrm{CaO}$ & 5.13 & 6.36 & 9.45 & 7.03 & 2.37 & 2.8 \\
$\mathrm{Na}_{2} \mathrm{O}$ & 2.36 & 4.34 & 2.51 & 3.72 & 1.54 & 3.2 \\
$\mathrm{~K}_{2} \mathrm{O}$ & 2.27 & 1.70 & 1.41 & 1.34 & 3.04 & 3.4 \\
\hline
\end{tabular}

Note: Analyses are given without volatiles and are recalculated to $100 \%$. Total iron is shown as $\mathrm{FeO}$.

1 = glass from experiments with a homogenized mixture of 0.34 basalt (Sample 487-20-2, $54 \mathrm{~cm}$ ) +0.66 mud (Sample 487-10-3, $50 \mathrm{~cm}$ ) (Table 6, analysis 1).

2 = andesite from the Paricutin volcano in Mexico (Eggler, 1972).

3 = glass from the contact zone of the basaltic layer "twolayered" experiment (Table 6, analysis 3 ).

$4=$ average composition of five basaltic andesites from the Paricutin volcano (Table 5, analysis 4).

5 = glass from the lower zone of the pelitic layer of the twolayered experiment (Table 6, analysis 4).

6 = garnet-bearing granodiorite from southeast Australia (Green, 1976).

that determines the variation of composition of the effusives in the calc-alkaline series.

In the second of our experiments, the process of partial melting is complicated by diffusion. Diverse petrogenetic components exhibit varying mobility during this process. On the whole, the chemistry of the melts in the pelitic and basaltic parts of the specimen were controlled by the composition of the initial materials: in the first layer melt coexists with the typical basic assemblage olivine plus plagioclase, and in the second layer it coexists with high-alumina phase (sillimanite?). Thus the chemical potentials of the principal petrogenetic oxides were not equalized along the entire length of the specimen during the time of the run. However, some components, and potassium in particular, exhibit significant mobility: $\mathrm{K}_{2} \mathrm{O}$ content is as high as $1.41 \mathrm{wt}$. $\%$ in the contact zone of the basaltic layer (Table 6, analysis 3 ), and although in the lower part of this layer it decreases to $0.73 \mathrm{wt}$. $\%$ (Table 6 , analysis 2), it is still substantially higher than in the initial basalt $(0.18 \mathrm{wt}$. \% [Table 5 , analysis 1]). We must note, however, that this increase of $\mathrm{K}_{2} \mathrm{O}$ content in interstitial glass in the basaltic layer may have been at least partly due to the accumulation of this component in the residual melt because of the crystallization of low-potassic phase (olivine and basic plagioclase).

On the whole, the chemistry of quenched glasses produced in the basaltic layer of the run is distinctly tholeiitic (Table 6, analysis 2). Only in the narrow zone of direct contact with pelitic material does diffusion result in the appearance of melts almost identical to basaltic andesite from the Paricutin volcano (Table 7, analyses 3 and 4). On the other hand, glass compositions in the pelitic layer are rather similar to the S-type granitic rocks (Table 7, analyses 5 and 6 ) produced during the melting of alumina-rich metamorphic rocks (Chapell and White, 1974).

\section{CONCLUSIONS}

1. Partial melting of the parts of ocean crust with varying ratios of magmatic and sedimentary rocks may explain the diversity of composition of calc-alkaline magmas.

2. Calc-alkaline magmas may be generated both during the anatexis of mechanically mixed material and the partial melting of layered series. In the latter process diffusion phenomena must play an important role.

\section{REFERENCES}

Chappell, B. W., and White, A. T. R., 1974. Two contrasting granite types. Pac. Geol., 8:173-174.

Dickinson, W. R., 1970. Relations of andesites, granites and derivative sandstones in arc-trench tectonics. Rev. Geophys. and Space Phys., 8:813-860.

1973. Width of Modern arc-trench gaps proportional to past duration of igneous activity in associated magmatic arcs. $J$. Geophys. Res., 78:3376-3389.

Eggler, D. H., 1972. Water-saturated and undersaturated melting relations in a Paricutin andesite and an estimate of water content in the natural magma. Contrib. Mineral. Petrol., 34:261-271.

Fitton, J. G., 1971. The generation of magma in island arcs. Earth Planet. Sci. Lett., 2:63-67.

Green, T. H., 1972. Crystallization of calc-alkaline andesite under controlled high-pressure hydrous conditions. Contrib. Mineral. Petrol., 34:150-166.

1976. Experimental generation of cordierite- or garnetbearing granitic liquids from a pelitic composition. Geology, 4 (No. 2):85-104.

James, D. E., 1978. On the origin of the calc-alkaline volcanics of the central Andes: A revised interpretation. Year Book Carnegie Inst. Washington, 77:562-590.

Magaritz, M., Whitford, D. J., and James, D. E., 1978. Oxygen isotopes and the origin of high ${ }^{87} \mathrm{Sr} / 86 \mathrm{Sr}$ andesites. Earth Planet. Sci. Lett., 40:220-230.

Oxburgh, E. R., and Turcotte, D. L., 1970. Thermal structure of island arcs. Geol. Soc. Am. Bull., 81:1665-1688.

Pichler, H., and Weyl, R., 1973. Petrochemical aspects of Central American magmatism. Geol. Rundsch., 62(2):357-396.

Ringwood, A. E., 1974. The petrological evolution of island arc systems. J. Geol. Soc. London, 130:183-204.

Ryabchikov, I. D., Bogatikov, O. A., and Babansky, A. D., 1979. The problems of the origin of calc-alkalic magmas. Vulkanologia Seismologia, 1:28-39. (In Russian)

Stern, C. R., 1974. Melting products of olivine tholeiite basalt in subduction zones. Geology, 2 (No. 5):227-230.

Stoiber, R. E., and Carr, M. J., 1974. Quaternary volcanic and tectonic segmentation of Central America. Bull. Volcanol., 37(No. 3):304-325.

Williams, H., 1950. Volcanoes in the Paricutin region, Mexico. Geol. Surv. Bull., 965-B:165-279. 